\section{Cancer data are puzzling}

\section{Washington}

THE US General Accounting Office (GAO) has uncovered a conundrum in breast-cancer therapy. Although there is good evidence from randomized clinical trials that chemotherapy following surgery is beneficial for premenopausal women with breast cancer that has spread to the lymph nodes, increased use of chemotherapy has not been followed by decreased mortality statistics. In 1987, Congress asked GAO - its investigative agency - to determine whether cancer patients were actually receiving the latest therapies being developed with federal money by the National Cancer Institute. In its latest report*, GAO used data from the Surveillance, Epidemiology and End Results (SEER) programme to track mortality from breast cancer from 1975, when chemotherapy was first shown to be an effective treatment, until 1983, the latest year for which complete data are available.

Although there is still some debate over the value of chemotherapy for breastcancer patients whose cancer has not spread to the lymph nodes, clinical trials have shown that for node-positive premenopausal women, chemotherapy is beneficial. Nevertheless, despite an increase in the number of women receiving chemotherapy between 1975 and 1983, there is no detectable change in survival figures. The analysis confirmed that age and race are significantly related to the probability of dying from breast cancer.

GAO proposes three explanations for its results. The first, and least likely, is that chemotherapy is not so beneficial despite studies to the contrary. A second possibility is that doctors are not giving appropriate or sufficient drugs to their patients, and a third possibility is that the improvement that can be expected from chemotherapy is not great enough to be detected by GAO's statistical techniques.

But Vincent DeVita, Physician-inChief at Memorial Sloan-Kettering Cancer Center and former director of the National Cancer Institute, says GAO is premature in raising the long-term survival issue. He argues that only a small fraction of the appropriate patient population was receiving chemotherapy in 1975, and newer therapies will yield a more encouraging picture in a few years. DeVita accuses GAO of designing its study to validate preconceived ideas.

The GAO report calls on the Department of Health and Human Services to conduct a larger study to explain the curious findings.

Joseph Palca

* Breast cancer: patients' survival. United States General Accounting Office, GAO/PEMD-89-9, Washington, DC, 1989.

\title{
Activists infiltrate Stanford
}

\section{Berkeley}

THE Stanford University biology faculty has become involved in a new controversy over the use of animals in research by criticizing an undergraduate course taught by two animal rights activists. A letter from the biology faculty objecting to the course was obtained by the two instructors, who are now demanding an apology.

Stanford has had difficult relations with animal rights activists for the past several years. Protesters have caused more than a year of costly delays for Stanford in building both a new animal facility and a new biology research building (see Nature 329, $477 ; 1987)$. So the biology faculty was dismayed to learn last autumn of a Stanford course called "The Case for Animal Rights", being taught by Kimberly Sturla

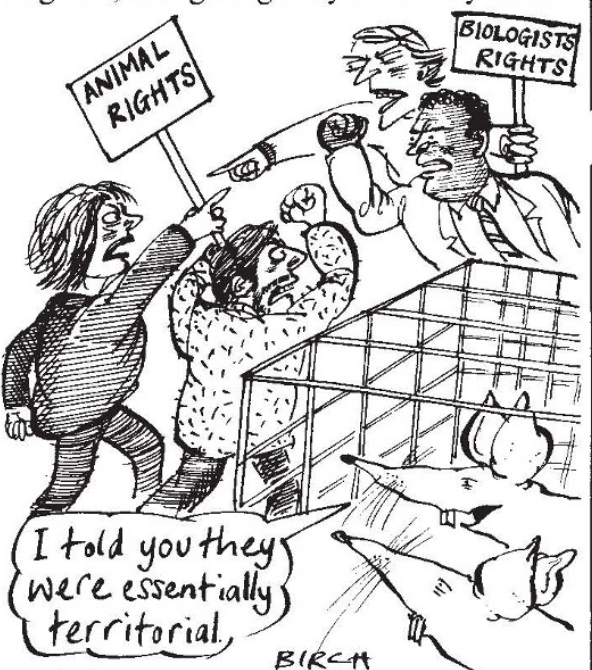
and Lise Giraud of the Peninsula Humane Society, both of whom have been involved in the building protests.

The course was part of a popular programme called Stanford Workshops on Political and Social Issues (SWOPSI), intended to expose students to controversial subjects. Biology chairman Philip Hanawalt says department members did not object to a course on animal rights, but were concerned because one of them who had attended the class reported that the instructors showed ignorance of the scientific arguments for using animals, and created a hostile environment for speakers invited to present that view. The faculty voted unanimously that a letter of objection should be sent to the dean of undergraduate studies.

"We decided that it is the prerogative and duty of the academic faculty to maintain quality control in what is taught to Stanford students", said Hanawalt, "and therefore it was entirely appropriate for us to make comments on this." Those who observed the class and wrote the letter have requested anonymity out of fear of reprisals by the activists.

The letter, which was addressed to
Thomas Wasow, dean of undergraduate studies, with a copy to Margo Horn, director of SWOPSI, questioned the qualifications and scientific knowledge of the instructors, and accused them of requiring ideological compliance of the students and of failing to present both sides of the issue. When the instructors heard of the letter and asked for a copy, Horn consulted Wasow, who agreed that she could send them one. Wasow says that at the time he did not consider the letter, which bore the names of the entire biology faculty, to be confidential. Hanawalt says such internal memoranda should be considered confidential. He compares its release to the instructors to the release to a faculty member denied tenure the letters upon which that decision was based.

Through their attorney, Sturla and Giraud have publicized the letter, called it "defamatory" and demanded an apology. Sturla claims she is "very qualified", to teach the course, and points out that the course dealt with issues other than research, such as the use of animals for food and in rodeos. She adds that in each case, experts were brought in to present each side of the argument.

David Maurice, a professor of ophthalmology who spoke in favour of animal use in research, says he was given a polite hearing, but felt that his words fell on deaf ears, as the students had already been strongly biased against animal use. Maurice, who himself co-taught a seminar on alternatives to animal use several years ago, questions whether activists like Sturla and Giraud are the right people to teach such a class.

Marcia Barinaga

\section{SCIENCE POLICY}

\section{Brazilian appointment São Paulo}

ConTinuing its quick-change approach to science and technology policy, the Brazilian government last week selected a secretary for its new Special Secretariat for Science and Technology, a cabinet-level body created just two months after the sudden extinction of the Ministry for Science and Technology. The appointment of Décio Leal de Zagottis, director of the influential Polytechnic School of the University of São Paulo, may signal a change in computer-industry policy. In the two months following the death of the old ministry, science policy and the management of several government institutes went to the Industry and Trade Ministry, whose minister, Roberto Cardosa Alves, opposes Brazil's protectionist stance towards the computer industry. The new secretary says he will oppose change.

Ricardo Bonalume Neto 